Вісник Дніпропетровського університету. Біологія. Екологія. - 2008. - Вип. 16, т. 2. - С. 122-126.

Visnyk of Dnipropetrovsk University. Biology. Ecology. - 2008. - Vol. 16, N 2. - P. 122-126.

УДК 581.1:631.4 (477.53)

$$
\text { Л. Д. Орлова }
$$

Полтавський державний педагогічний університет ім. В. Г. Короленка

\title{
ХІМІЧНИЙ СКЛАД MELILOTUS (FABACEAE) ПОЛТАВЩИНИ
}

Розглянуто хімічний склад надземної маси Melilotus albus Medik. і M. officinalis (L.) Pall. Наведено кількісні характеристики вмісту органічних (протеїну, жиру, клітковини, безазотистих екстрактивних речовин) і мінеральних (загальної золи, кальцію, фосфору) речовин. Показано динаміку їх накопичення. Вказано шляхи практичного використання цих видів.

$$
\text { L. D. Orlova }
$$

V. G. Korolenko Poltava State Pedagogical University

\section{CHEMICAL COMPOSITION OF MELILOTUS (FABACEAE) OF THE POLTAVA REGION}

Chemical composition of above-ground mass of Melilotus albus Medik. and M. officinalis (L.) Pall. is considered. The quantitative descriptions of content of organic (protein, fat, cellulose, nitrogen-free extractive substances) and mineral (total ash, calcium, phosphorus) matters are presented. The dynamics of their accumulation is shown. The ways of usage of these species are indicated.

\section{Вступ}

Кожний вид рослин характеризується специфічним, властивим тільки йому набором хімічних речовин. Він складався і відбирався протягом багатьох поколінь. До складу рослинних організмів, як і інших живих істот, входять три групи речовин: вода, органічні сполуки та мінеральні речовини. Але кількість, якісний склад, співвідношення їх у конкретних видів досить суттєво відрізняються на фоні специфічних рис будови та пристосувань до умов середовища. Хімічний склад рослин обумовлюється багатьма чинниками. У першу чергу це індивідуальні особливості: видова специфіка, фаза розвитку, тривалість життя тощо. Разом із тим, синтез і накопичення речовин залежать від умов зростання: грунтових, кліматичних, а також інших факторів.

Трав'янисті фітоценози відрізняються від інших своїми характерними рисами. Тому рослини, які там оселяються, мають певні анатомо-морфологічні та екологоценотичні особливості, формують специфічний, притаманний тільки конкретним видам, хімічний склад. Одним із таких родів, представники якого зростають на степових ділянках, луках, узліссях, прибережних пісках, засмічених місцях, є Melilotus Mill.

Melilotus - досить поширена група рослин у трав'янистих фітоценозах Полтавської області. Їх еколого-ценотичні особливості добре висвітлені в літературі як нашими дослідженнями [10-12], так і роботами інших авторів [1;2]. Крім того, у роботі I. В. Кирпичова та С. Ю. Наумова наводяться нові відомості про біологічні особливості однорічних і дворічних форм Melilotus albus Medik. [7]. Дослідники показали специфічні риси формування вузла кущіння та занурення його у грунт, дали оцінку відповідності використання агроприйомів потенціалу виду щодо зимостійкості.

(С) Л. Д. Орлова, 2008 
Хімічний склад Melilotus дається в середньому по СРСР [9], Україні [15], окремим регіонам $[13 ; 15]$. Для Полтавщини таких відомостей нами не виявлено. Вказуються лише кормові характеристики Melilotus в умовах культивування або при підсіванні у природні травостої при внесенні добрив [5]. Тому основна мета наших досліджень - охарактеризувати вміст хімічних речовин у надземній масі Melilotus, які зростають на луках Полтавської області.

\section{Матеріал і методи досліджень}

Об’єкти досліджень - два найпоширеніші на Полтавщині види Melilotus: M. albus Medik. та M. officinalis (L.) Pall. У природних умовах дослідження проводилось за загальноприйнятими методами, основними серед яких були маршрутний і напівстаціонарний. Характеристика видів наводиться з урахуванням робіт П. Ф. Медвєдєва та О. І. Сметанникової [9], Н. В. Артюкова [1]. Оцінка біоекологічних властивостей рослин базувалася на працях О. Л. Бельгарда [3].

На пробних ділянках зрізали надземну масу рослин, яку далі в лабораторних умовах висушували, подрібнювали та відбирали середню пробу для подальшого аналізу. Вміст води визначали шляхом висушування у сушильній шафі при температурі $+105^{\circ} \mathrm{C}$, золи - озоленням у муфельній печі, нітроген - за методом К'єльдаля, клітковину - за методом Геннеберга та Штомана, жир - за методом Попандополо, протеїн - шляхом перерахунку вмісту азоту на коефіцієнт 6,25, безазотисті екстрактивні речовини (БЕР) - відніманням від 100 вмісту води, протеїну, клітковини, жиру, золи (у \%), фосфор - колориметричним, кальцій - комплексометричним трилонометричним способом [6].

\section{Результати та їх обговорення}

M. albus та M. officinalis - типові представники родини Fabaceae Lindl. Вони відносяться до високорослих трав'янистих рослин із тривалістю життєвого циклу два (рідше один) роки. Мають добре розвинену стрижневу кореневу систему з розгалуженнями, прямостоячі або висхідні стебла, що утворюють досить об'ємний кущ висотою 1,02,0 м. Генеративні пагони закінчуються колосоподібним суцвіттям із квіток метеликового типу. Плоди - невеликі боби одно-двонасіннєві. Розмножується в основному насіннєво, але може і вегетативно, шляхом поділу коренів [9].

За реакцією на умови зростання досліджені види входять до груп: по відношенню до освітлення - геліофітів, до температурних умов - мезотермів з високою морозостійкістю, до зволоженості - мезофітних видів, але характеризуються досить високими посухостійкими властивостями. Вони невибагливі до грунтових умов, $є$ олігомезотрофами. На думку І. В. Кирпичова та С. Ю. Наумова, ці представники першими можуть оселятися по днищах ям, канав, коли інші види флори існувати там не можуть через малу кількість поживних речовин [7].

У вивчених травостоях досліджені види зустрічаються поодиноко, але можуть бути домінантними на невеликих площах, особливо на порушених місцях [10; 11].

Для проведення порівняльного аналізу (табл. 1) використано літературні дані інших авторів: для СНД (СРСР - європейської частини) - за П. Ф. Медвєдєвим , О. І. Сметанниковою [9], Лівобережного Лісостепу (в середньому) та Полісся - за Й. А. Даниленко зі співавторами [15], Донбасу - за Є. М. Кондратюком зі співавторами [13]. Зроблений нами хімічний аналіз надземної маси обох видів наведено у таблиці 2.

Зольність і вміст жиру у M. albus у Полтавській області нижчі, ніж наводиться у літературі. Кількість клітковини, яка є основним показником перетравності кормів тваринами, також менша, ніж указують інші автори. Ця ознака підвищує цінність корму 
для годівлі тварин із наших луків. До того ж, уміст протеїну та БЕР перебуває на межі середніх показників для робіт інших дослідників. У M. officinalis спостерігається подібна до M. albus ситуація щодо накопичення золи, БЕР та клітковини. Жири взагалі дуже мало концентруються у наших зразках (у 1,3-3,4 раза менше від літературних даних). Протеїну міститься середня кількість, подібно до умов Полісся та середніх даних для Свропейської частини СНД, але менше, ніж у Донбасі та в цілому для Лісостепу України.

Таблиия 1

Хімічний склад M. albus та M. officinalis (\% на суху речовину) різних місць зростання (за П. Ф. Медвєдсвим , О. І. Сметанниковою [9], Й. А Даниленко зі співавторами [15], С. М. Кондратюком зі співавторами [13])

\begin{tabular}{|c|c|c|c|c|c|}
\hline \multirow[b]{2}{*}{ Вид } & \multirow[b]{2}{*}{ Показник } & \multicolumn{4}{|c|}{ Місце зростання } \\
\hline & & Донбас & Полісся & $\begin{array}{l}\text { Лісостеп } \\
\text { України }\end{array}$ & СНД \\
\hline \multirow{5}{*}{ M. albus } & зола & 7,6 & 9,3 & 8,7 & $7,0-8,0$ \\
\hline & протеїн & 19,4 & 28,7 & 17,0 & $16,0-22,0$ \\
\hline & жир & 2,4 & 2,9 & 2,6 & $2,0-4,0$ \\
\hline & клітковина & 27,4 & 23,6 & 25,2 & $24,0-34,0$ \\
\hline & \begin{tabular}{|l|} 
безазотисті \\
екстрактивні речовини \\
\end{tabular} & 43,4 & 40,5 & 50,4 & $30,0-45,0$ \\
\hline \multirow{5}{*}{$\begin{array}{l}\text { M. offi- } \\
\text { cinalis }\end{array}$} & зола & 7,2 & 7,5 & 6,9 & $6,4-12,3$ \\
\hline & протеїн & 21,4 & 16,2 & 18,4 & $14,5-21,5$ \\
\hline & жир & 3,6 & 3,8 & 2,2 & $1,4-3,7$ \\
\hline & клітковина & 23,7 & 30,8 & 32,9 & $24,4-35,0$ \\
\hline & $\begin{array}{l}\text { безазотисті } \\
\text { екстрактивні речовини }\end{array}$ & 44,1 & 45,5 & 41,5 & $40,1-52,3$ \\
\hline
\end{tabular}

Таблиия 2

Хімічний склад M. albus та M. officinalis (\% на суху речовину) в умовах Полтавської області

\begin{tabular}{|l|c|c|}
\hline \multicolumn{1}{|c|}{ Показник } & M. albus & M. officinalis \\
\hline Зола & $5,7 \pm 0,8$ & $6,9 \pm 0,5$ \\
\hline Протеїн & $18,7 \pm 2,7$ & $16,2 \pm 3,2$ \\
\hline Жир & $1,2 \pm 0,1$ & $1,1 \pm 0,06$ \\
\hline Клітковина & $21,6 \pm 2,2$ & $22,6 \pm 2,14$ \\
\hline Безазотисті екстрактивні речовини & $45,6 \pm 4,7$ & $44,6 \pm 3,34$ \\
\hline
\end{tabular}

Уміст основних поживних речовин (золи, протеїну, жиру) у M. albus нижчий, ніж у M. officinalis. Концентрація БЕР менша у M. officinalis порівняно з M. albus. Зменшена кількість клітковини у зразках M. albus говорить про ії кращу поїдальність, ніж M. officinalis. Динаміка вмісту хімічних сполук за роками у фазі бутонізації - квітування показала, що у M. officinalis накопичення золи, жиру коливається мало $(0,2-1,0 \%)$. Накопичення протеїну за роками варіює досить сильно (17,6-21,8 \%), як і концентрація клітковини (20,1-24,1 \%). Вивчення змін показників у M. officinalis довело, що вміст золи, жиру так само, як і у M. albus, мало коливається $(0,5-1,0 \%)$. Концентрація протеїну мінялася більше (13,0-18,5 \%), ніж у клітковини $(21,1-24,1 \%)$.

Якісний склад золи бобових, зокрема вміст кальцію та магнію, має свої особливості. Відомо, що вміст лужного кальцію майже завжди перевищує кількість кислотного елементу фосфору [15]. У M. albus концентрація фосфору у середньому була 0,5 \%, а кальцію - 0,7 \%, у M. officinalis - 0,5 та 0,8 \% відповідно. Уміст цих елементів за роками дослідження показав, що більше він змінюється під впливом зовнішніх умов у фосфору, менше - у кальцію. 
Для годування сільськогосподарських тварин велике значення має співвідношення елементів у кормах. У роботі Ш. В. Алексанян зі співавторами [16] показано, що кращим показником співвідношення кальцію до фосфору є 1:1 або 2:1. У наших умовах таке співвідношення складає у випадку з $M$. albus - 1,4, у M. officinalis - 1,6. Тобто воно входить у кращі норми для повноцінного годування тварин.

Наявність такого хімічного складу у M. albus та M. officinalis дає змогу використовувати їх як цінні пасовищні рослини багатопланового використання. Урожай зеленої маси з успіхом використовується для виготовлення трав'яного борошна, сінажу та силосу. Доведено, що у 100 кг маси Melilotus може міститься 20-22 кормові одиниці [7]. Як показали наші попередні дослідження, у травостоях з участю вивчених видів цей показник був у межах 16,5-21,2 [7]. Але тут потрібно пам'ятати, що використання у великих кількостях бобового корму не рекомендується через можливості розвитку різних захворювань типу тимпаніту, особливо при переважанні Medicado L. чи Trifolium L. Також (через наявність кумарину) трава і сіно мають гіркуватий смак і неприємний запах, тому до годування ними тварин потрібно підходити поступово, щоб вони звикали. Можна їх використовувати як фітомеліоративні рослини на солонцях, пісках, крутих схилах, ерозійних ділянках.

Окрім того, є відомості про використання цих рослин у медицині, оскільки в них наявні фармакологічно активні речовини. Наприклад, у народній медицині вживають усі частини M. albus з різною терапевтичною метою. M. officinalis, як говорить сама назва, широко використовується як у народній, так і у офіційній фітотерапії різних країн [14]. Вивчені рослини - медоноси та пергоноси. Медопродуктивність чистих заростей M. officinalis до 150-200 кг/га, M. albus - до 500 кг/га [8].

Наявність кумарину в усіх частинах рослин надає їм характерного аромату, особливо відчутного при висушуванні. Порошок висушеної трави додають до певних сортів тютюну для ароматизації, а також у деякі напої [14].

Інколи, нечасто, M. officinalis та M. albus можуть бути бур'янами в посівах. Частіше за все засмічують посіви гороху, горошку, вівса, проса, озимих жита і пшениці тощо. За сприятливих умов можуть навіть пригнічувати сільськогосподарські культури. Основними заходами боротьби є старанна обробка грунту, догляд за посівами, обкошування узбіч доріг до плодоношення або хімічні методи [4].

\section{Висновки}

Хімічний склад M. officinalis та M. albus на луках Полтавщини свідчить, що надземна маса їх містить велику кількість корисних сполук. Рослини невибагливі до зовнішніх умов, але кількість органічних і неорганічних речовин у надземній частині сильно варіює залежно від умов зростання. Тому при використанні досліджених видів у практиці тваринництва потрібно проводити зоотехнічний аналіз у конкретних регіонах.

\section{Бібліографічні посилання}

1. Артюков Н. В. Донник. - М.: Колос, 1978. - 107 с.

2. Багаторічні бобові трави / Під ред. Б. С. Зінченка. - К.: Урожай, 1985. - С. 98-106.

3. Бельгард А. Л. Лесная растительность юго-востока УССР. - К.: КГУ, 1950. - 264 с.

4. Бур'яни України (визначник-довідник). - К.: Наукова думка, 1970. - С. 206-207.

5. Гриб Н. И. Полтавская ордена Трудового Красного Знамени сельскохозяйственная станция им. Н. И. Вавилова / Н. И. Гриб, В. К. Чуйко. - К.: Либідь, 1991. - 232 с.

6. Журавлев В. М. Руководство по зоотехническому анализу кормов. - М.: Сельхозиздат, 1963. $-295 \mathrm{c}$. 
7. Кирпичев И. В. Однолетний и двулетний донник / И. В. Кирпичев, С. Ю. Наумов. - Луганск: ЛГАУ, 2000. - 100 с.

8. Луговые травянистые растения: биология и охрана. Справочник. - М.: Агропромиздат, 1990. - C. 110-111.

9. Медведев П. Ф. Кормовые растения европейской части СССР / П. Ф. Медведев, А. И. Сметанникова. - М.: Колос, 1981. - С. 86-90.

10. Орлова Л. Д. Біорізноманіття та екологія кормових представників родини бобових луків Полтавщини // Зб. наук. праць Полтавського державного педагогічного університету ім. В. Г. Короленка. Серія Екологія. Біологічні науки. - 2001. - Вип. 3 (17). - С. 69-76.

11. Орлова Л. Д. Участь представників родини Бобові (Fabaceae Lindl.) у створенні лучних травостоїв Полтавщини // Зб. наук. праць Полтавського державного педагогічного університету ім. В. Г. Короленка. Серія Екологія. Біологічні науки. - 2004. - Вип. 4 (37). - С. 14-21.

12. Орлова Л. Д. Біоморфологічна та еколого-ценотична характеристика Melilotus Mill. Полтавщини // Зб. наук. праць Полтавського державного педагогічного університету ім. В. Г. Короленка. Серія Екологія. Біологічні науки. - 2005. - Вип. 3 (43). - С. $39-45$.

13. Природные растительные кормовые ресурсы Донбасса / Под. ред. Е. Н. Кондратюка. - К.: Наукова думка, 1985. - С. 48.

14. Растительные ресурсы СССР: Цветковые растения, их химический состав, использование; Семейства Hydrangeaceae - Haloragaceae. - Л.: Наука, 1987. - С. 159-161.

15. Хімічний склад і поживність кормів / Й. А. Даниленко, О. О. Перевозіна, А. А. Кацукова та ін. - К.: Урожай, 1975. - 348 с.

16. Хімічний склад і поживність кормів півдня України / Ш. В. Алексанян, Р. В. Логвинова, 3. Г. Грабовецька та ін. - К.: Урожай, 1970. - 101 с.

Надійшла до редколегї 15.02.2007 